\title{
VOTE NO: ARCHBISHOP WALSH, THE CATHOLIC CHURCH AND THE 1944 NEW JERSEY CONSTITUTION
}

\author{
BYNICHOLAS TURSE \\ Nicholas Turse is an Archival Processor/Researcher at the New Jersey \\ Department of State, Division of Archives and Records Management
}

In 1947, the state of New Jersey cast out its I844 Constitution that had become an antiquated, patchwork liability, and adopted a modern document that became a model for excellence. When this 1947 Constitution was in development, the powers backing it made conscious and conspicuous effort to rally support behind the new document. After a plethora of failed attempts at revision, nothing was left to chance. Foremost among groups courted for support of the constitution was the Roman Catholic Church. To comprehend and appreciate the need for and eventual gain of Catholic support of the "new" 1947 Constitution, one must fully examine the issues and innerworkings of the Church's previous opposition. By doing so one can see a political shift not only in the Church, but also in power and policy in New Jersey as a whole.

\section{Constitutional Reform and the Battle Among Politicians}

Beginning in the winter of 1940-194I, New Jersey began a drive for a new constitution. After numerous proposals and abortive attempts at calling a constitutional convention, constitutional reform had become an issue during the 1940 gubernatorial campaign, which pitted Franklin D. Roosevelt's Secretary of the Navy (and Thomas Edison's son), Democrat Charles A. Edison, against the Republican New Jersey Senator Robert C. Hendrickson (Fig. 5). Hendrickson ran his campaign by attacking Edison as a "puppet of state Democratic boss Frank Hague," and pushing for election and court reforms via amending the 1844 Constitution. ${ }^{1}$ Edison, for his part, ran on the theme of being "Independent." Far from being a "puppet," Edison was actually sent by FDR to "wrest control of the pro-Roosevelt forces in the

Journal of the Rutgers University Libraries, Vol. LIX, pp. I-?

Copyright 2000 by the Rutgers University Libraries. All rights reserved. 
state away from Hague." 2 He took subtle jabs at Hague abuses, and pushed for revamping the state's outmoded administrative system and for a stronger office of the governor. In late October, I940, Edison stated, "[the I844 Constitution] has not stood the test of time. If elected, one of my first official acts will be to ask the legislature to authorize a constitutional convention." ${ }^{3}$ While this issue did not become a major focal point during the final days of the campaign, Edison would keep his promise.

Democrat Charles A. Edison was elected Governor of New Jersey without even carrying his own "home" county (thanks to I07,000 Hudson County votes delivered by Frank Hague). In his victory speech, Edison highlighted the need for constitutional reform. ${ }^{4}$ These sentiments were repeated in his inaugural address when he stated, "under a properly modernized constitution, I believe your governor could save the people millions of dollars each year."

While politicians wrangled with the question, citizens' organizations moved towards reforming the constitution. Having endorsed the issue of a constitutional convention in both 1939 and 1940, the League of Women Voters (LWV) of New Jersey initiated a convention drive in early I94I. The LWV named political scientist John E. Bebout from Newark University its technical advisor. At a meeting of state civic, political, organizational and educational leaders on February 24, I94I, an "umbrella" organization called the New Jersey Committee for Constitutional Convention (NJCCC) was created, for all interested in such reform.

Governor Edison's appeal for a constitutional convention had gotten a cold reception in the state legislature. Edison again formally requested one in an address to the legislature on July 28. Bowing to Republican pressure, Edison now would accept representation based upon legislative representation. On this same day, the last before summer recess, in both the senate and the assembly, Republicans introduced new convention bills. Thus, as they headed into the fall, prospects for a convention seemed brighter.

Another event that aided constitutional reform came about in July when an open rift developed between Frank Hague and Charles Edison (Fig. 6). Hague became enraged when the governor, with the assistance of the legislature, initiated a plan of debt forgiveness and tax breaks with state railroad interests. Jersey City, as well as other Hudson County towns, contained much of the railroad property in New Jersey. During the Depression the railroads had accrued massive debts, and went on a "taxstrike" to remain solvent. Edison not only forgave \$I7 million in debt, 


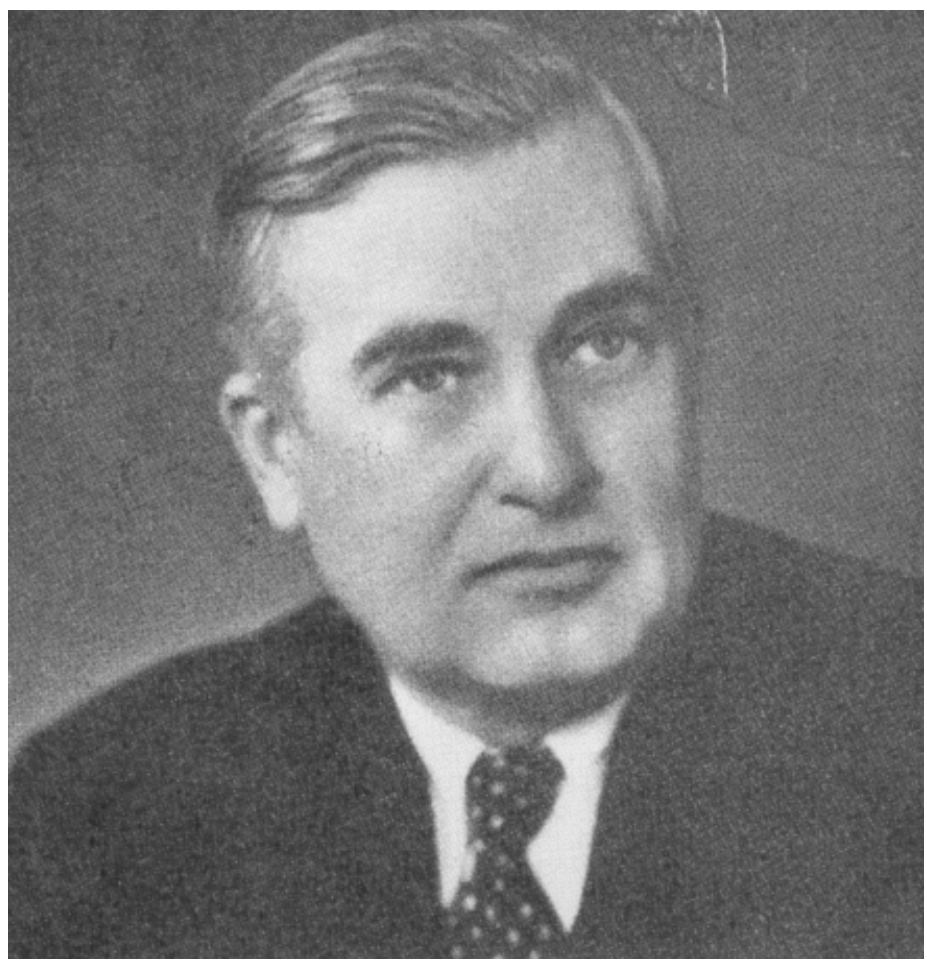

Fig. 3.1 Photo of Governor Charles A. Edison. (From Special Collections and University Archives) 
penalties, and back-interest, but also gave the railroads a low tax rate for the future. Hague was incensed by Edison's "sellout" and washed his hands of many responsibilities as Democratic Party chief. Dumping the obligations for the party convention and the upcoming legislative campaign upon Edison, Hague hoped to bury the governor. Instead, Edison used the added powers to appoint pro-Edison men to the Democratic ticket.

During the campaign and election of I94I, Edison fought for a constitutional convention, while stumping for "Edison Democrats." Yet, his work was to little avail as Republicans increased their majority in both the senate and the assembly. Outside of Hudson County, Democrats were "steamrolled" by Republicans, and Edison had no doubts that Hague was responsible, having instructed "Democratic workers throughout the state to sit on their hands." 5

When the legislature reconvened, the GOP summarily created a commission to study the necessity of proposing amendments in I942, having deemed it too late in the year to actually amend the constitution in 194I. The Essex Republicans pressed for a broader scope for the commission. This commission would be appointed by the governor (two appointments), the speaker of the assembly (two appointments) and the president of the senate (two appointments), with the six members choosing the seventh. Edison appointed Arthur Vanderbilt and Senator Crawford Jamieson (an anti-Hague Democrat); Senator Hendrickson and John Sly of Princeton University were the senate president's appointees; and the assembly speaker appointed Walter Freund (a Bergen County freeholder) and Judge Walter Van Riper of Essex County. James Kerney, the editor of the Trenton Times, was chosen as the seventh member, and Charles Erdman of Princeton and lawyer Walter Miller became staff members. ${ }^{6}$

With an obvious lack of pro-Hague men on the commission, some rumblings began to emerge from Jersey City. A pro-Hague assemblyman let it be known that Hudson County would only support constitutional revisions made in the interests of "all of the people," and not a commission that aimed to "suit themselves and the interests they represent," namely, according to Hague, the railroads. ${ }^{7}$

It was decided early in deliberations that the I844 Constitution could not effectively be amended and that a new document must be drafted. Using the recent New York constitution (I938), a 1929 Institute of Public Administration survey dealing with "the state's administrative and fiscal 


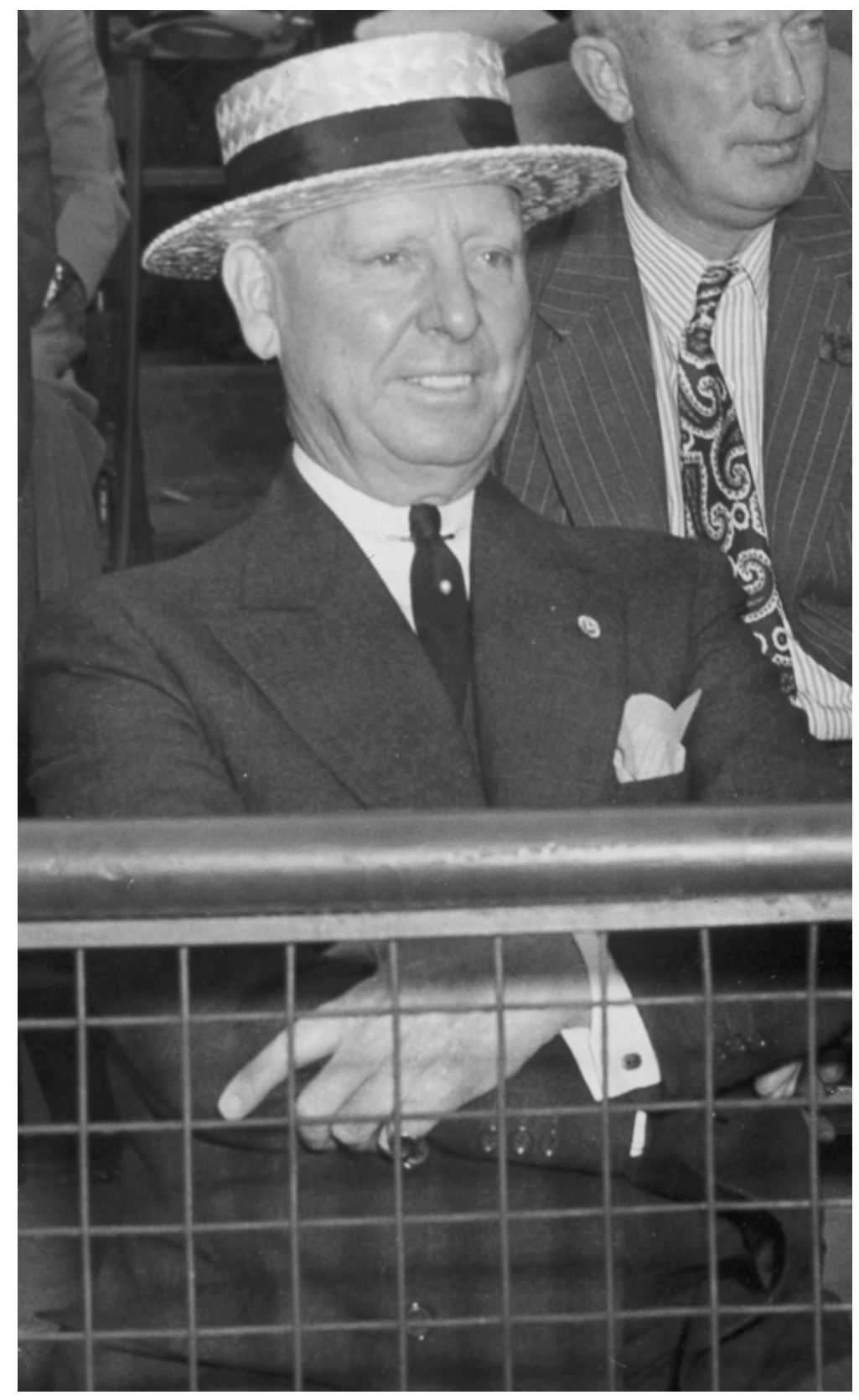

Fig. 3.2 Photo of Frank Hague at Roosevelt Stadium in early 1940s. (From Special Collections and University Archives) 
machinery," papers prepared by the New Jersey Judicial Council, and a number of Princeton University surveys, the "I942 Draft Constitution" came into being. ${ }^{8}$

This "draft," however, was never to become the official constitution for New Jersey. The commission was not able to "sell" their document to the rural "anti-revisionist" counties of the state, nor were they able to garner legislative support. The "Draft Constitution" was referred to the judiciary committee where it further languished until June I5. On this date, the GOP initiated a bipartisan legislative committee to evaluate public opinion on the draft constitution and constitutional reform in general. Both the drafting commission and the NJCCC were decidedly against this new committee. Called a "reactionary obstruction" by Constitutional Commission member James Kerney, the committee was composed of officials unfriendly to the new constitution (six of the members were either small county Republicans or Hague Democrats). In order to counter this, the NJCCC held public hearings, speeches, and general meetings throughout the summer and fall of 1942, attempting to ensure the constitution a place on the November ballot. This was not to be. Frank Hague blasted the constitutional revision on the grounds that it could not be voted on while so many were serving in the military overseas. Eleven Jersey City disabled veterans backed this sentiment reiterating Hague's sentiments before the joint committee. Following this display, the joint committee came to the decision that the New Jersey constitution should not be revised "until after the termination of the present war."

With the report of the committee being handed down, and the legislature unwilling to undertake any constitutional reforms during the remainder of the year, the NJCCC had to accept defeat in 1942. In debt, and without widespread political support, the NJCCC met with Governor Edison in the hope of acquiring governmental assistance. This they received with the founding of the New Jersey Constitutional Foundation (NJCF). This organization was created to "conduct and stimulate education on the history, character, and efficiency of the constitution and government of New Jersey." ${ }^{10}$ Designed to create a popular grassroots movement, the NJCF had decided advantages over the NJCCC; most importantly, donations to the NJCF were tax deductible. While the NJCCC continued its lobbying efforts, its sister organization started "educational" endeavors, distributing pamphlets and flyers preaching constitutional reform. 
In 1943, the drive for constitutional reform began again. A GOP measure in the spring called for a November referendum to decide whether to authorize the legislature to draft a constitution in I944. Clearing caucus, the bill then won a 37 to 14 vote in the assembly and was sent to the senate. The Feller Bill (as it was known) encountered trouble in the senate. The NJCCC and the NJCF began a pressure campaign, mailing flyers and requesting citizens to write their senators, while Governor Edison also tried unsuccessfully to influence the senate with speeches. Although the measure failed, the constitutional issue had become such a large part of New Jersey politics that it invariably got enmeshed in the upcoming governor's race.

The election of 1943 brought a "new" man onto the constitutional scene, the Republican candidate Walter Edge (Fig. 7). Edge began to champion constitutional reform well before the election. He was instrumental in moving the Feller Bill through both legislative houses, thereby allowing New Jersey voters to choose "whether they wanted the 1944 legislature to act as a limited constitutional convention." "I The NJCF and NJCCC soon endorsed this measure, carrying out a publicity campaign in favor of the bill.

While constitutional reform became a major tenet in the GOP gubernatorial campaign, it was not a neglected issue on the Democrat ticket either. Candidate Vincent Murphy, mayor of Newark and trustee of the NJCF, attempted to walk a fine line between the positions of Hague and Edison. He bowed to Hague's pressure and condemned Edison's railroad tax laws, but, unlike the Jersey City boss, he favored the constitutional referendum.

November 2, 1943 brought with it the election of Walter Edge and an approval of the constitutional referendum measure. Edge claimed that the citizens of the state had delivered a mandate giving the Republican Party "complete executive and legislative responsibility" to reform New Jersey's constitution. With this, Edge set out on a torrid pace, pushing a revised constitution through both the assembly and the senate within six weeks of his inauguration. ${ }^{12}$

\section{Catholic Involvement in Constitutional Reform: Starting at the Top}

On September 27, 1944, Governor Edge made a clandestine visit to speak with Newark Archbishop Thomas J. Walsh. Edge, his Attorney General Walter D. Van Riper, and the governor's secretary, Edward M. Gilroy, met 
with Walsh at the Newark Chancery building for about forty-five minutes. Neither Walsh's personal files nor his 1944 calendar book contain any information about this meeting. While Walsh's attitude about the conference remains largely unknown, Governor Edge's autobiography, A Jerseyman's Journal, offers a view of Walsh as a man who had already made up his mind about the issue. Edge writes that the meeting he and his staff had with the archbishop could "not in conscience be called a discussion." Edge states that he "point by point... went over the revised constitution," that Van Riper buttressed a few legal points about the issue of divorce, and that Walsh listened "attentively" but without much input. Edge writes that the Archbishop then "stood up and the audience was ended." Walsh's action does not seem to have been taken out of a personal dislike for or hostility towards the governor, as only a few months earlier he had been cordially invited to Edge's daughter's wedding. Therefore, it seems the archbishop had his own agenda, and may have finalized his decision concerning the constitution well before Edge's visit. ${ }^{13}$

At the meeting, the governor is alleged to have explained his view that the revised constitution in no way threatened the Church. He is also said to have "assured the archbishop he would not stand in the way of an amendment to the constitution for bus transportation and said he was sympathetic to such a bill." Edge is also supposed to have cited the statements of two antirevisionist priests (Father Farrell of Asbury Park and Monsignor Peter B. O'Connor of North Arlington) as instances of "unfair" clerical opposition to the proposed constitution, and to have asked that such activities "be curbed." This Walsh refused. ${ }^{14}$

What was the basis for Archbishop Walsh's opposition to this new constitution? The involvement of the church hierarchy prior to this meeting only deepens the mystery.

\section{Church Hierarchy Explores The Issues}

While lay Catholics had been involved in constitutional reform from its beginnings, the Catholic Church hierarchy began to treat the matter as a major issue in late 1943 and early I944. Just prior to the 1943 Election Day, Reverend Ralph Glover received a letter from the New Jersey Committee for Constitutional Revision (NJCCR) urging him to vote for the constitutional referendum. The letter itself is of little importance, as it was a form letter sent to thousands of voters. Its recipient, however, would play 

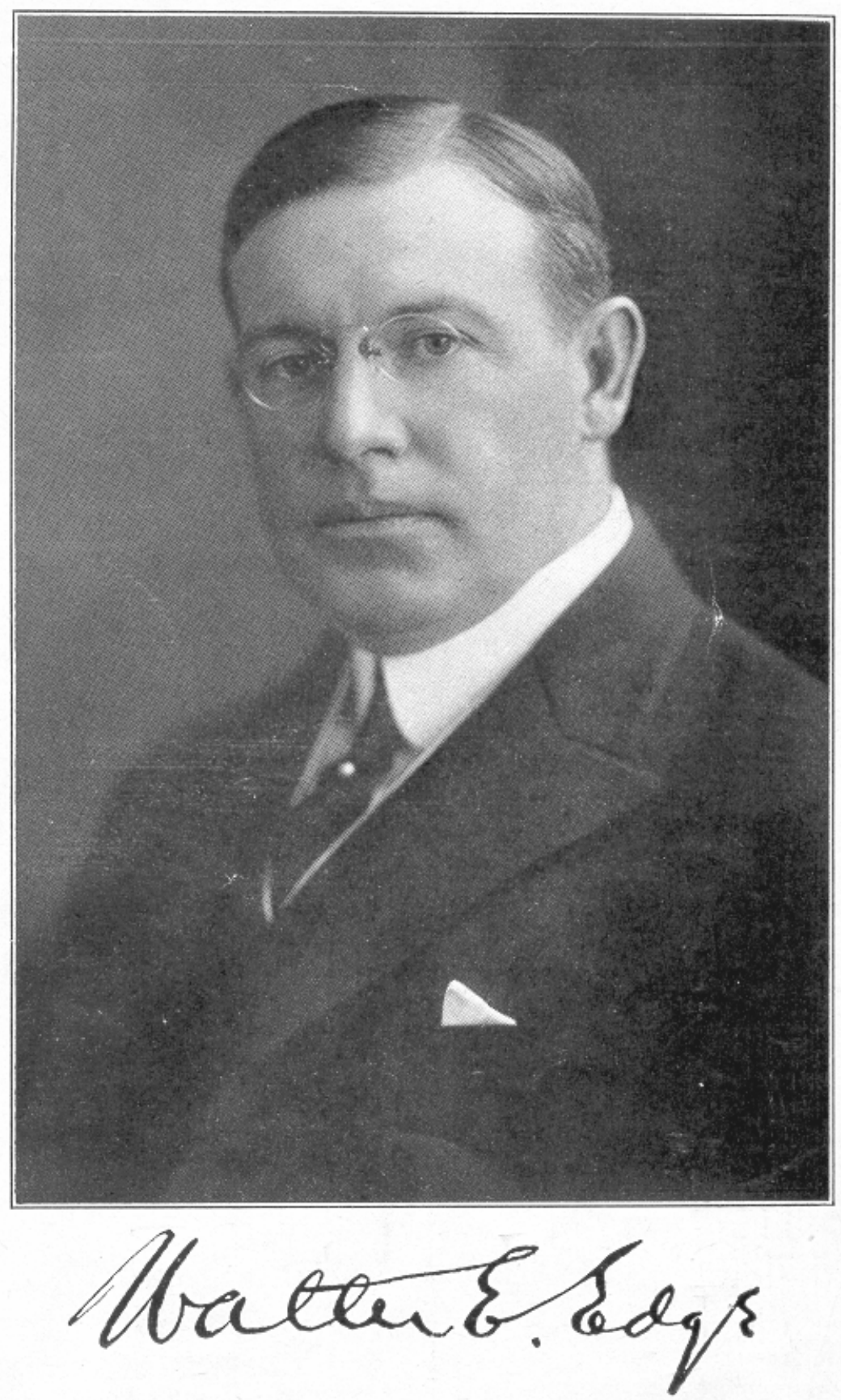

Fig. 3.3 Photo of Walter E. Edge. (From Special Collections and University Archives) 
a large role in the ecclesiastical response to the proposed constitution of 1944.

Monsignor Ralph Glover was the executive director of Associated Catholic Charities and, among numerous other positions, the head of the Catholic Legislative Council of New Jersey. Appointed by Archbishop Walsh of Newark, Glover often acted as the Archbishop's liaison in dealing with the state government of New Jersey. Monsignor Glover's papers reveal his strong interest in revision of the constitution. From the beginning of 1944 through Election Day, Glover compiled a voluminous file of newspaper clippings on all aspects and opinions about the constitutional question from no less than ten different papers.

In late January, Archbishop Walsh discussed with the bishops of Paterson, Camden, and Trenton "his desire for the [ir] cooperation ... in defending Catholic interests with reference to the proposed revision of the constitution of the state of New Jersey," and the submission of names of "suitable Catholic lawyers" to serve on the legislative council. Glover began to receive correspondence from the bishops, listing the names of those designated to serve, as well as personal instructions.

The first of the Catholic Legislative Council of New Jersey meetings for the new year presided by Monsignor Glover was held on February 25, I 944 at the Archdiocese of Newark Chancery Building. The purpose of the I944 council was defined immediately: "There are three definite problems as I see the work outlined for this year ... [The first is the] decision as what we are to do or how we are to educate our Catholic people in reference to this constitutional revision. We should make a definite study of it, know our position and know what action and what stand we are going to take." 15 Following the initial statement, an agenda was set. While all members of the council were to review the entire document so that they might make suggestions, it was decided to divide the various sections of the revised constitution into Rights and Privileges, Legislative, Executive, and Judiciary committees for intensive study. Each diocesan delegation became responsible for one committee and pledged to issue a report at the next meeting. ${ }^{16}$

On March 3, the second meeting of the 1944 New Jersey State Legislative Council was called to order. The first committee to respond was Rights and Privileges, chaired by Newark Mayor Fred J. Gassert, who directly stated: "I have examined it. I find nothing harmful to the Church in the articles." The next to respond was Francis N. Reps of Trenton, a member of 
the Legislative committee, who said that "[There is] Nothing in the proposed revision that would in my opinion effect [ sic] us one way or another." The Judiciary committee chair, Camden's prosecutor Gene R. Mariano, reported on the section that dealt with the power of the governor. Mariano unequivocally stated, "I see nothing which effects [sic] the Church." The final committee, Paterson's Judiciary, stated that save the possibility that members of other committees wished to discuss section three, article four (which dealt with the "maintenance and custody of children"), "there is nothing that will require any action by this body." A deadline for creating a definitive Catholic stance on the proposed constitution was set for June I and the meeting was soon adjourned. While other meetings would follow, this particular exchange yields some of the most telling information. All four committees, without exception, concurred that the "new" constitution would not injure Catholic interests and none spoke against the document in any way. Due to these facts, it would seem the official Catholic legal advisory body in New Jersey had given the constitution a de facto endorsement. ${ }^{17}$

The next meeting, held on March 24, contained very little discussion of the constitution. Monsignor Glover stated he had secured a copy of the recently revised New York State Constitution and wished to compare it with the New Jersey revision. Judge John J. Rafferty, delegate from Trenton and the personal representative of Bishop Griffin, requested clarification of the council's power in reference to the proposed constitution, and Glover responded that the legislative council would provide the bishops with a recommendation on the appropriate action to undertake. ${ }^{18}$

At the April I4 session, Monsignor Glover made it a point to remind all in attendance that our "bishops are looking to us to get a very definite suggestion and program from this group as to their procedure." Formal reports were slated for the next meeting and the council adjourned. ${ }^{19}$

On April 28, 1944, Judge Rafferty, the chairman of the state committee, issued a report on article seven, paragraph four of the revised constitution. This particular piece dealt with tax exemption statutes, an issue of particular interest to the church. In the revised constitution, the only tax exempt property was of veterans of the armed forces, so that some worried that this might lead to church property being taxed. Rafferty's committee concluded that tax exemption of church property would "remain effective and constitutional if the proposed revision [was] adopted." The state group's report was made into a proposal and was adopted. ${ }^{20}$ The importance of the resolution cannot 
be overstated, as the tax issue would figure greatly in Catholic politics during the late weeks of the constitutional campaign.

On May 5 the next session of the council was held, with the state committee issuing a report, at the request of Monsignor Glover, about the possible discrimination against charitable institutions. Again, the committee found that the issue was a "matter of statutory law and not a matter of administrative regulation." ${ }^{21}$

On May I2, 1944, the council again met. This time the state committee discussed article five, section three, paragraph three, sub-division three of the revised constitution, which dealt with transferring matrimonial actions from equity courts to the law courts. This particular issue split the committee. Rafferty argued that the transfer of such matters to law courts made divorce easier because "it is no improvement on the present system." 22 Committee member Nolan countered that "in the new constitution there is nothing new about divorce than is in the old constitution except jurisdiction is transferred from the equity courts to the law courts." Nolan went on to say that law courts deciding matrimonial cases was, in other states, common practice and was without negative repercussions. Nolan further stated that "so far as Catholics are concerned, this constitutional revision makes no difference to them one way or another." 23

\section{The Bus Bill}

At the next meeting of the New Jersey State Legislative Council, the state committee again focused on the matrimonial matter. Before that discussion started, however, an issue of more than passing importance was brought up, namely, the "Bus Bill." The Bus Bill was a I94I law that authorized bus transportation for students of parochial schools. The Bus Bill had long since been passed by the legislature, but was still fighting its way through the court system. While the bill had no direct correlation to the proposed constitution, it was a subject of great interest to Catholics around the state. Before discussion of the revised constitution took place, Thomas Madden asked John Rafferty if, were the Bus Bill to be declared unconstitutional by the courts, the council would come back into session (as the council was nearing the end of its spring session and would be going on its summer break). Rafferty stated that if it was decided "against us, we go to the Court of Errors" (the next prescribed legal recourse). ${ }^{24}$ 
Discussion resumed on the matrimonial issue. Judge Bartholomew A. Sheehan of the Camden delegation took the point further saying, "we should ask [for a constitutional provision which states] that no grounds for divorce will be recognized in this state." While Sheehan's views were hard-line, they were against divorce and not the Equity to Law Court transfer. On this latter issue, Judge Sheehan's position was that "as a Catholic [he] ha[d] no objection to the proposed transfer." Martin Loftus of Paterson agreed with Nolan's statements of the previous meeting that "there is nothing that we should oppose or favor as Catholics." 25

On Friday, May 26, I944, the final meeting of the spring session of the council got under way. Oddly enough there is no mention of the revised constitution in the minutes or notes from the meetings, although in leafing through the file containing the meeting notes that deal with the work of the federal committee, one finds the State of New Jersey: Revised Constitution booklet. ${ }^{26}$

Out of session for the summer, the New Jersey State Catholic Legislative Council left no final "yes or no" answer to the constitutional question, but it seems most members felt no great need to oppose the document. Thus, without a formal decree, the official legislative advising body to the Catholic Church of New Jersey had spoken.

In mid-September 1944, the Supreme Court of New Jersey struck down the Bus Bill as being unconstitutional. This sent a shockwave through the Catholics in the state. From this point forward religion would play a major role (whether or not it was acknowledged) on both sides of the constitutional fight.

On September 20, I944, the Frank Hague-friendly Jersey Journal ran an editorial titled, "Blow at Hague Hits Clergy, Doctors, Lawyers and Press." The fact that clergy was placed first underscores the brewing religious issue. Called "dangerous" and referred to as "political scheming," the paper argued, the revised constitution would be opposed by "every clergyman." 27

Even with the religious concerns raised in connection with the defeat of the Bus Bill, the Church legislative council's benign view of the proposed new constitution would seem to preclude any official Catholic activism against the constitution. Yet, as Archbishop Walsh's response to the Governor's visit indicated, a strong yet shadowy opposition was soon to be felt. 


\section{The Campaign for a Constitution}

Since Walsh had given Edge his (de facto) decision, the governor attempted to circumvent the archbishop and speak to the Catholic populace directly. The Jersey Journal reported on October 22 that Governor Edge

was, in speeches and appeals, "going out of his way to calm Catholics and assure them ... they have nothing to fear from the proposed new state constitution." The article stated that along with Edge, former Governor Charles Edison was also traversing the state reassuring Catholics that Church property would not be taxed, priests would not be forced to betray the secrets of the confessional, divorces would not be made easier, and that the new constitution would allow a greater chance for the bus issue to be resolved. It remains unclear who was, as Governor Edge put it, "making unfortunate misrepresentations in an attempt to persuade Roman Catholics that the document would be detrimental to their religion and Church." ${ }^{28}$ Surely, Hague was behind such a plot; but was Walsh too?

Walsh's files concerning this matter are conspicuously sparse; however, a major clue emerges in the Newark News of October 23, 1944. In an article entitled, "Pamphlet Attacks Charter Revision," an unidentified nun from Montclair, in Essex County, attested to having received an anonymous twentyeight-page pamphlet urging votes against the revised constitution. The nun claimed she had received the booklet through the mail. This document utilized the anti-revision arguments of Church taxation, easy divorce, and the Bus Bill. It is at this juncture that a possible tie to the ecclesiastical leader is found. ${ }^{29}$

In a file box from the Ralph Glover papers, amidst a group of papers not housed in a folder (the only such papers in the rather large collection), there is a document marked "confidential" and dated three days before the newspaper article. This letter of October I0, 1944, reads:

Confidential

Distribution of Manuals - I to a House

Discussion of Manual

Sister to take Manual to her Convent and there read it and have it read and studied and mastered and used by all the Sisters of the given Convent.

All Sisters registered to Vote should Vote $\underline{\mathrm{NO}}$ on the Revised Constitution and should by presentation of the facts of the Manual induce lay women to Vote $\underline{\mathrm{NO}}$. 
Sisters should not make known except to Sisters the fact that this meeting was held. All Sisters should strive to obtain Voters $\underline{\mathrm{NO}}$

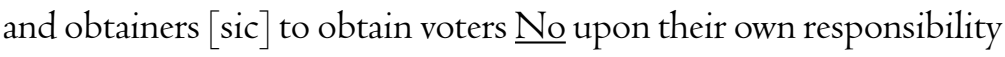
with the use of the Manual. Sisters should be prudent and diligent and should not discuss this question on the telephone and should not use the name of the Archbishop or any ecclesiastical authority publicly or privately. ${ }^{30}$

This confidential memo, found in the Glover files, also bears the signature "Monsignor Glover" upon the reverse. Furthermore, Richard Connors reprints (from a copy in the John Bebout files) excerpts from the twentyeight-page manual the Montclair nun received titled A Study of the Proposed Revised Constitution of the State of New Jersey. This same pamphlet was also found in Monsignor Ralph Glover's files. All of this evidence points to one thing: that the Church, and specifically Archibishop Walsh, was involved in this matter.

The most critical evidence, however, that seals the verdict on Glover and Walsh, are various drafts of the "nun" pamphlet found in Monsignor Glover's files. One handwritten partial copy, complete with "cross-outs" in the handwriting of Glover, was also discovered in the files of the director of the Associated Catholic Charities, paper-clipped to the "Confidential Memo." Other typed copies, which included attached revisions, were also in Glover's private files. In reading said drafts, we are privy to handwritten notes specifying what should be italicized and where words should be inserted, and we see these reworkings in the final pamphlet. ${ }^{31}$

Whether the nun had leaked the information out of spite towards the ecclesiastical "command" remains unclear. What is clear is that the ecclesiastical chief had disregarded the findings of the New Jersey State Catholic Legislative Council, which had found no problems with the Churchtax issue. It is also clear the council did not advocate the idea of using the constitutional issue as retribution for the Bus Bill. Obviously, the council's findings were not integral to the decision; there was a higher political agenda at stake, which was either set by the archdiocese of Newark hierarchy or by Democratic boss Frank Hague.

The day after the "Nun Pamphlet" story broke, the Jersey Journal reported that former Governor (and Hague-ite) A. Harry Moore attacked the revised constitution on the grounds of Church taxation. Moore stated that "the things left out of this constitution are more important than the 
things they put into it." While Attorney General Van Riper asserted that there were no plans to tax churches, Moore countered by saying that Van Riper could not guarantee that future legislatures would not approve a tax. Moore further attacked the revision by saying that, since the state had already waited one hundred years, why couldn't it wait another year or two until New Jersey's 500,000 men in the armed forces had come home? ${ }^{32}$

On October 26, 1944, Governor Edge again attempted to confront the religious issue. In a letter to Spencer Miller, president of the NJCCR, Edge declared: "I hate a religious war but they have not played fair and I shall not accept this attack lying down." Just whom Edge really meant by "they" is not explicitly stated. While he may have meant both Walsh and Hague, he usually reserved his public barbs for the Jersey City mayor. That same day the Bergen Evening Record reported, "Edge Charges Hague Misleading Catholic on True Facts of Constitutional Revision." In the article, the Governor was quoted as saying, "Hague ... is resorting to a new falsehood, a new lie, a new appeal to a religious or racial group each day in his fight against the new state constitution." Edge also addressed the Bus Bill question, stating "the new charter had no direct or indirect reference to this type of legislation." Edge's stump-mate Charles Edison also issued a statement, saying he was "sorry" the revision campaign had become an "anti-Hague battle." Edison countered charges that the new charter was created to destroy the Jersey City mayor, saying adopting a new constitution to "get at one boss would be like using a field gun to kill a fly." 33

The "fly," however, was just gearing up his own attack. Hague announced that for the first time in ten years he would travel outside Hudson County during a campaign, making anti-revision speeches. The mayor attacked the revision as a vehicle to destroy the Democratic party, a Republican document designed to bilk money from the pockets of Jerseyans into railroad coffers, while quietly stirring the religious issue. To counter Hague's campaign, Edge played his own Catholic card, helping to organize the Catholic Committee for Constitutional Revision (CCCR). This group, headed by NJCCR vicechairman (and Trenton Times editor) James Kearney, Jr. and Secretary of State James Brophy, was made up of Catholic laymen in favor of the new constitution. In an undated letter from James Kerney to Monsignor Glover, the Trenton Times editor stated that, "The Church will not in any way be injured [by the constitution]. If we [the CCCR] did not feel strongly that every right of the church will not be protected and the new constitution is 
good for everybody in New Jersey, we would not have joined in its endorsement." ${ }^{34}$

As the Catholic Committee for Constitutional Revision mounted its publicity campaign, on October 27 a number of New Jersey daily papers wrote headlines saying "Catholic Group Endorses New Constitution," "Catholics Back Charter; Score Bigotry Attack," and "Catholic Committee for New State Constitution." Nearly all such newspapers reprinted (in whole or in part) the statement released by the group countering the "unfounded and scurrilous attacks on the new constitution." The committee, purported to have been founded in less than twenty-four hours, called upon other Catholics to join the pro-revision fight. ${ }^{35}$

Supplementing the CCCR's message, Attorney General WalterVan Riper blasted Frank Hague as the only opposition to the new charter, and implied that Hague was behind rumors that Church property would be taxed. That same day the pro-Hague Jersey Journal ran an editorial attacking the revised constitution for allowing "easy" divorces. The religious battle gained a new warrior on October 28, when Judge William Sewell entered the fray. Sewell came out in favor of the revision, stating that Church taxation was an unfounded fear purveyed by "desperate" opponents of the constitution. Sewell claimed that churches were not endangered by the document and that the uproar was created by men who were "throwing aside all restraint ... making an all-out appeal to the fears, passions and prejudices of our people." In the same vein, the former assistant corporation attorney for Hoboken, James A. Coolahan, refuted the claims that the proposed constitution endangered the "right $[\mathrm{s}]$ and privileges of Catholics," calling the opposition "propaganda." Not to be outdone, lawyer Frederick M. P. Pearse, former secretary to Governor George S. Silzer, came out in opposition of the new charter on the grounds that the document might lead to taxation of religious organizations. ${ }^{36}$

In the October 30 Elizabeth Journal, an article chronicled the denunciation of the revision by the Elizabeth Council, Knights of Columbus, on the grounds of the Church taxation issue, as well as the Bus Bill. The Knights of Columbus also attacked the CCCR's statement that opposition to the proposed constitution was based upon religious bigotry, calling that statement "an insult to the I,400,000 Catholics in the state." The same newspaper issue also contained a short piece titled "Churchmen Defend Charter," which reiterated the CCCR opinion and called for a "yes" vote. ${ }^{37}$ 
The end of October brought on the greatest onslaught in the fight for the Catholic vote. Although Edge had asked Walsh to silence him all the way back on September 27, on November I Monsignor Peter O'Connor again assailed the new charter. In a speech before 600 people in the school hall of Our Lady Queen of Peace, North Arlington, O'Connor called for "vote against the nefarious proposed constitution to protect their 'rights and interests as Catholics'." While attempting to avert conspiratorial questions, O'Connor stated "I hold no brief for Mr. Hague," but went on to say that the "Gestapo"-like document had "borrowed from Hitler to hamstring Hague." Further attempting to distance himself from "partisan" issues, O'Connor stated that he opposed the constitution on three legislative grounds. Again, the Bus Bill and tax exemption were put forth. A third issue, however, deviated from the norm, as O'Connor cited the fact that "the people were refused an opportunity to hold a convention." This argument was one that Hague had recently been stressing. ${ }^{38}$

About the same time as O'Connor's speech, Monsignor Ralph Glover sent out a message (at the direction of Archbishop Walsh) to pastors across the state. In the letter Glover requested that additional copies of the magazines the Catholic News and the Tablet, containing articles opposing the proposed constitution, be prominently displayed in the vestibules of churches on Sunday, November 5. Glover, who had already had double the usual number of issues sent to each parish, also made arrangements for pastors to order still more copies directly from each editor. ${ }^{39}$

On November 3, 1944, Governor Edge and former Governor Edison again tried to diffuse the religious issue. Edge stated that the "attempt of Hague to regiment the Catholic Church against constitutional revision will become a boomerang and that it will be resented in the same way that it was in 1875 when the church opposed a series of constitutional amendments." The governor said that the distinctions between ecclesiastical and political lines had broke down and the (non-Catholic) public resented it and voted for the amendments. Edge then laid into Hague with comments such as calling his actions "vicious and unprincipled," and saying "Hague stoops to the depths of religious bigotry." Edge again attempted to counter claims that the document assailed the Catholic Church. In reference to the sanctity of the confessional, he stated that the new charter "in no way affects the confidential relationship now existing in churches, " that despite what "Hague stooges were saying ... divorce will not be changed in any way," and finally, 
that "every priest ... who will read the revised constitution must know it continues unchanged our present freedom of religion." 40

Edison, too, made an eleventh hour attempt against the Catholic issue. Speaking before the Bayonne Knights of Columbus, Edison denounced the circulation of "anonymous and scurrilous pamphlets" harking back to the October 23 story. The former governor charged that the "anti" manual "was a disservice to [the] religion of which its sponsors should be thoroughly ashamed," and pointed to the CCCR and their endorsement of the proposed constitution to prove the revision was not detrimental to Catholics. Edison stated that he "prayed that no Catholic man or woman w[ould] vote against the constitution on the basis of the unfortunate representations." With his appeal finished, he began an onslaught against Frank Hague. Calling the Jersey City mayor "a dictator," "a bully and a coward," the former governor asserted that "truth has never stood in the way of Hague or his henchmen and they are not going to change their habits at this late date." Edison ended his speech professing that the revision was not enacted to "get Hague," evidencing his statement by asserting that the revision movement went back "long before Hague, 'as old as he is.". 41

In Constitutional Revision in New Jersey, Richard J. Connors makes special reference to Saturday, November 4, writing "it was revealed that an unsigned letter had been received by Catholic pastors, 'directing' them to instruct their parishioners to vote against the constitution." Connors states that the Chancery Office of the Newark archdiocese declined to comment on the letter. However, the papers of Monsignor Glover shed new light on the subject. A typed letter in the Glover files, complete with its original written draft paper-clipped to it, offers proof of what Connors hints at. The undated letter reads:

Letter -

We would ask you to read the enclosed important announcement, Sunday, November 5, without comment or explanation. Should you be asked the reason or source of the announcement your answer should be: "No comment." This letter is personal and confidential to you.

T.J.W.

Announcement -

The proposed revised state constitution should not be supported. Why remember the Bus Bill. Vote "No." 
Response - Jersey City

Not admitting your alleged information, I intend to continue my opposition to the constitution as a citizen according to my own plans and specifications.

While the existence of the letter alone would seem enough to negate the need for confirmation by the Chancery Office, evidence that the note is indeed the "official" document alleged by Connors to have been sent is found in the words of the parish priests. ${ }^{42}$

The Newark Sunday Call reported that churchgoers at the I a.m. mass in St. John's Roman Catholic Church heard Reverend David F. Kelley, "speaking rather rapidly," recite: "The proposed revised constitution should not be supported. Why? Remember the school bus bill. Vote 'no'." (Father Kelley later made it a point to state that "The Catholic Church has never instructed her children how to vote.") In Jersey City, the Hudson Dispatch reported how Catholic parishioners were advised, "The proposed revised state constitution should not be supported. Why? Remember the Bus Bill. Vote "no'." The Dispatch further stated that the "announcement was made at all masses yesterday [November 5] but no specific comments were made." The Jersey Observer also echoed this story reporting that parish priests asked for a "no" vote. Both the Dispatch and the Observer went on to say that priests refused to comment upon the voting advisement they issued. The Newark Sunday Call stated that "reports have been current that all priests in Newark archdiocese would advise against revision today [November 5]," while the Jersey Observer stated that "the action of the Catholic clergy yesterday [November 6] was generally reported to be 'Bishop's Orders'." The Dispatch contacted a number of parishes and reported that one church admitted "that the request to warn against votes for revision came from the office of the archbishop." 43

The typed letter, signed T.J.W. (the initials of the Archbishop), was, as previously stated, attached to a handwritten rough draft. Upon inspection of the draft, it is apparent that Archbishop Walsh did not write it, as it is not in his distinctively large and grandiose script. The handwriting, however, does appear to be that of Monsignor Ralph Glover. This, added to the fact that the letter was found in Glover's personal files, points to the fact that once again Glover carried out the clandestine wishes of the Archbishop, as he had for the anonymous "nun pamphlet."

Upon hearing that "Catholics were asked at church yesterday [November 
5] for a blanket vote against the proposed constitution," Governor Edge expressed "deepest regret." Edge went further to claim that Mayor Hague had "dupe[d] the Catholics into a blind vote on this non-partisan, nonreligious issue." He claimed once again that Hague had "done the state of New Jersey and its citizens the greatest disservice of his shabby political career by arousing unfounded fears among the clergy of the Catholic Church." Edge also went on to state that he had sent telegrams to the heads of the Catholic Church in the state, "concerning the efforts to have Catholics oppose the new constitution." While he declined to state what exactly had been sent in the telegrams, he did say that he had sent such a communication to Walsh, as well as the other bishops of New Jersey. ${ }^{44}$ In keeping with Walsh's papers on the subject of the 1944 proposed constitution, no such telegram seems to have been filed.

On the day before the election, the man who "hate[d] a religious war" took to the airwaves to again dispel Catholic doubts and fears about the proposed constitution. Edge attacked Hague and the mayor's assertion that churches would be harmed by taxation allowed by the new charter. The governor pointed to the CCCR and its endorsement of the revision. Once more, Edge tried to convey that the Bus Bill had nothing to do with the new charter, save that it was declared unconstitutional under the old charter. Attempting to extend the olive branch, rather than calling them "dupes" (as he had already done that same day) he more tactfully stated that "the clergy ha[d] been misled and know not what they do." He placed the blame firmly upon Hague saying, "it is a sad commentary on a dying political machine when it stoops to religious bigotry ... to deprive people of a better state government through the new constitution." The next day would decide if the "dying" Hudson machine and Newark's Archbishop would triumph over Edge. ${ }^{45}$

A Catholic voting-bloc against the constitution, or as Walter Edge later contended, a "confused abstention," sealed the fate of the revised constitution of 1944, with a vote of 789,956 to 663,435. An interesting addendum to the entire Catholic battle against the proposed state constitution appeared in the Plainfield Courier News just three days after the vote. Monsignor James F. Kelley, president of Seton Hall College, called for the "rancor engendered by the state constitutional revision" to be ended immediately. Seemingly forgotten by this point was the fact that Kelley, called a "spokesman" for Walsh by the Oranges and Maplewood, had himself worked 
for constitutional revision during the early stages of the revisionist drive. ${ }^{46}$

New Jersey's 1944 bid for a revised constitution boiled down to a struggle pitting the Democratic boss, Frank Hague, against Republican Governor Walter Edge, and that November marked the last major victory for the Hague machine. As a series of opposition governors was cutting away at Hague's patronage powers and the ethnic makeup of his constituency changed, the lack of "new blood" in the organization and an increasing degree of absenteeism on the part of the mayor (who was often vacationing in posh locales) sapped the political clout of "New Jersey's Hitler," culminating in the victory of John V. Kenny over Frank Hague Eggers in I949. But in 1944, "Boss Hague" still held enough power to defeat the constitution, primarily by his ability to command the Catholic vote.

\section{Why "Boss Hague" and Archbishop Walsh Teamed up to Defeat the Constitution}

In viewing Archbishop Walsh's files, it is evident that he was no mere Hague pawn. When A. F. Heck, campaign director of the Community Chest of Jersey City, wrote to Archbishop Walsh asking for Catholic support for the program, Walsh declined as it was his (and Monsignor Ralph Glover's) opinion that such involvement would negatively affect Catholic interests. The fact that the letter prominently featured the name of Frank Hague as endorsing the measure seemed to have little effect. ${ }^{47}$ It would seem the archbishop was on at least a substantive, if not equal, footing with Hague. These facts then beg the question: Why did Walsh throw his considerable political power behind Hague's anti-revision crusade?

The answer to this question is the tremendous amount of patronage Hague still commanded over the Catholic Church. This "service for good will" policy (Connors' phrase) of Frank Hague would seem to be the reason. That the Catholic Church's assault upon the new charter coincided with Hague's major push against the document is not very surprising considering Hague's history of relations with the Church. Hague was himself a Catholic and mayor of a large Catholic constituency. Further, throughout the I920s and 1930s Hague's vehement anti-Communist stance, stringent control over local bars and emphasis on social values - stressing the importance of family and the sanctity of womanhood - evoked public clerical support. ${ }^{48}$

By the 1944 election, Hague's ties to the Roman Catholic Church in New Jersey were well documented. As the New Republic reported in I938, 
"He [Hague] can count on the support of the Catholic hierarchy and many of the Church's rank and file.” In January I944, columnist William Weiner expanded on these sentiments saying Hague's "chief support" came from the Church, and "it is no secret that Hague has curried favor with the hierarchy for years.” Weiner went on to chronicle Hague's support of Catholic charity drives to the "extent of assessing his jobholders for contributions," his employment of some two dozen priests as city chaplains, and his importing an altar from Italy to donate to a Jersey City church. Not surprisingly, when one looks at the employment record of Monsignor Ralph Glover before he became head of the Associated Catholic Charities of Newark and the official Catholic liaison to the proposed constitution, we find he was assistant pastor of St. Paul of the Cross Church, Jersey City. Further, at the time of the creation of the Associated Catholic Charities of Newark one of the "proud... Founders" that donated a sizable sum of money (which, he wrote, gave him "a great deal of pleasure") was none other than Frank Hague. ${ }^{49}$

Hague's ties to the Newark archdiocese are further chronicled in Connors' biography of the Jersey City mayor, A Cycle of Power: The Career of Jersey City Mayor Frank Hague. Connors states that Hague and Catholic powers of Newark became close-knit at an early stage of the mayor's career. The "Dictator: American Style" befriended and allied himself with Monsignor Sheppard, the vicar-general of the Newark diocese and pastor of Hague's parish. Connors states that the friendship between the two "was furthered by Hague's placing of persons on public payrolls at the monsignor's request, his consummation of property deals between the city and the churches that were advantageous to the latter, and other acts."

Aside from his dealings with others in the archdiocese, Hague must have curried great favor with Walsh himself. When the archbishop, who called Hague's Jersey City "the greatest city on the Atlantic Sea Board," came to Newark in 1928, he found a mansion had been purchased for the diocesan seminary located in Darlington (Bergen County). Walsh's official biography states that the bishop "recognized from the first" that the present structure was ill suited for a seminary and made the Seminary of the Immaculate Conception his pet project. Unfortunately for Walsh, the Depression made raising the estimated \$I,500,000 a major obstacle. Walsh's biography states the he established "The Bishop's Associations of the Clergy, of the Religious, and of the Laity" to raise the necessary funds. And while thanking "priests and people" when the goals were achieved, he failed to 
give special mention to one of the most important "people," Frank Hague. Connors flatly states, "Mayor Hague personally pressured city and county office holders into making generous contributions to a fund for a major seminary at Darlington, New Jersey." Thomas J. Fleming, in his American Heritage piece titled, "I am the Law," echoed this fact, saying, "Hague helped Archbishop Thomas Walsh of Newark raise millions for Darlington Seminary. Such an action by Hague, having done a great service for the archbishop, may have given Hague just the leverage he needed to call in a favor of his own in the future. ${ }^{50}$

As far as concrete evidence linking Walsh and Hague, there is little to go on. As historian Hermann K. Platt writes of Hague's files, "it seems that what papers there were, were all destroyed." ${ }^{51}$ Walsh's files, however, yield more clues than Hague's. In fact, the absence in his personal papers of information about dealings with Hague or the entire constitutional issue of I 944 is tremendously conspicuous. But Walsh kept meticulous files about everyone and everything concerning the Catholic Church, not only in the Archdiocese of Newark and the state of New Jersey, but in the entire world. When scanning the papers it is nearly impossible to miss the very thick file dealing with the 1947 Constitution (which both a weakened Hague and the Catholic Church hierarchy endorsed). Yet nothing, not even a scrap of paper, exists under a heading for the 1944 Constitution. One cannot help but ask, where is the copy of the "vote no" letter signed "T.J.W."? Why is there no file dealing with Frank Hague? Why doesn't the meeting with Governor Edge appear in Walsh's appointment calendar? Why is the proposed constitution, which would cause such damage to the Catholic Church, totally neglected by the Archbishop? Whether Walsh specifically never kept such files, or they were lost or destroyed, makes little difference; their absence speaks as loudly as if confidential communiqués between the Archbishop and the Mayor were found.

In a final examination of the Catholic opposition, it is clear that Archbishop Walsh did a great deal to defeat the proposed constitutional revision of 1944. Walsh, through Monsignor Ralph Glover, had anonymous pamphlets drafted and issued to religious orders throughout the state, so priests might "preach" against the proposed constitution, and issued memoranda ordering them to call for a vote of "no." He deliberately attempted, although not very well, to carry out his campaign in a clandestine manner. The New Jersey Catholic Church's connections to Frank Hague 
obviously played a major role in the decision to oppose the charter. So, too, may have Walsh's personal debt to Hague for the financing of the Darlington Seminary. Catholic animosity over the failed Bus Bill may also have contributed to the opposition. Yet, as Thomas Fleming writes in New Jersey: A History, the official "religious" reasons for church opposition advanced by Walsh were "tortured at best." If Walsh actually had true objections to the proposed constitution, they were never voiced, leading one to believe that the Catholic ecclesiastical opposition to the proposed constitution of I 944 was not so much a "religious issue," as it has often been identified, but a political one. 52

Notes

I. Richard J. Connors, The Process of Constitutional Revision in New Jersey: 1940I947(New York, 1970):24; New Jersey: Spotlight on Government (North Plainfield, NJ, I969):23.

2. "Lyle W. Dorsett, A. Frank Hague, Franklin Roosevelt, and the Politics of the New Deal,” Maxine Lurie, ed., A New Jersey Anthology (Newark, NJ, I994):405.

3. Newark Evening News 24 October, 1940 (in Connors, op. cit:25).

4. Connors, op. cit::25

5. Connors, op. cit: 34

6. Connors, op. cit::35

7. Jersey Journal 25 Nov. I94I (in Connors, op. cit:36)

8. Connors, op. cit:25-4I. For a detailed analysis of the "I942 Draft Constitution" see Connors, op. cit.: I-45.

9. Connors, op. cit:43-48; State of New Jersey, Record of Proceedings Before the Joint Committee Constituted Under Senate Concurrent Resolution No. I9 (Trenton, NJ, 1942):868-869.

I0. Connors, op. cit:58; New Jersey Constitutional Foundation Press Release, 28 December, 1942 (in Connors, op. cit:55).

II. Connors, op. cit:58-68.

12. "Pick Your Own Figures: In Essex You Can Have County's I79,398 Votes for Dewey or State's 178,989," Newark Evening News 6 December, 1944; Connors, op. cit:76.

I3. "Edge Asked Archbishop for Silence on Charter," The Newark Star Ledger 27 November, I944; Connors, op. cit.:IOI-I02; Walter Evans Edge, A Jerseyman's Journal: Fifty Years of American Business and Politics (Princeton, 1948); Wedding Invitation from Governor and Mrs. Walter Evans Edge to Archbishop Thomas J. Walsh, Walsh Files, Seton Hall University Archives, Archdiocese of Newark Collection.

I4. "Edge Asked Archbishop for Silence on Charter," The Newark Star Ledger 27 November, I944; Connors, op. cit::IOI-I02.

I5. Notes, Catholic Legislative Council of New Jersey Meeting, 25 February, I944:I. Folder, "Ralph J. Glover Papers," Seton Hall University Archives, Archdiocese of Newark Collection. 
16. Notes, Legislative Council Meeting, 25 February, I944:3-4.

17. Notes, Legislative Council Meeting, I0 March, I944:5.

18. Notes, Legislative Council Meeting, 24 March, I944, 3.

19. Notes, Legislative Council Meeting, I4 April, I944, 2-3.

20. John J. Rafferty, "Report of the State Committee," 28 April, I944:I; Notes, Legislative Council Meeting, 28 April, I944:I.

2I. John J. Rafferty, "Report of the State Committee," 5 May, I944:I; Minutes, Legislative Council, 5 May, I944:2.

22. John J. Rafferty, "Report of the State Committee," I2 May,I944:I-2.

23. John J. Rafferty(?), "Mr. Nolan's Minority View," I2 May, I944:I.

24. Connors, op. cit.:I00; Minutes, Legislative Council, I9 May, I944:2.

25. Minutes, Legislative Council, I9 May, I944:4-5.

26. Legislative Council (I94I; I944) (I9 May, I944-7 November, I944).

27. "Blow at Hague Hits Clergy, Doctors, Lawyers and Press," The Jersey Journal 20 September, 1944.

28. "Edge Asks Catholics Aid Charter: Denounces Claims New Charter Would Affect Churches," The Jersey Journal 22 October, 1944.

29. "Pamphlet Attacks Charter Revision; Document Received by Montclair Nun Cites Bus Bill,” Newark News 23 October, 1944; Connors, op. cit::I05.

30. "Confidential Memo: Distribution of Manuals - I to a House”; Discussion of Manual, 20 October, 1944:I.

3I. "Confidential Memo: Distribution of Manuals - I to a House"; Discussion of Manual,20 October, I944:I; A Study of the Revised Constitution of the State of New Jersey, 9; Connors, op. cit:I05. Handwritten partial draft and typewritten copy with revisions draft of A Study of the Revised Constitution of the State of New Jersey, Glover Papers.

While the identity of the "Montclair Nun" was never publicly revealed, it is probable that she was either a member of the Sisters of Charity, stationed in Montclair at Immaculate Conception or at St. Vincent's Hospital; of the Dominican Sisters of the Third Order of St. Dominic stationed at St. Lacordaire in Upper Montclair; or of the Filippini Religious Teachers at Our lady of Mt. Carmel, Montclair. See Louis Kenedy, ed., The Official Catholic Directory: Anno Domini 1944 (New York, 1944).

32. Moore, however, failed to state that any legislature could have enacted such a tax at any time during the previous one hundred years but had not. "Moore See Church Tax in Revision; All Faiths Hit, He Charges at Trenton Rally," The Jersey Journal 24 October, 1944.

33. Letter from Walter Edge to Spencer Miller, 26 October, I944, Folio 36, Edge Papers, quoted in Connors, op. cit.:I06; "Edge Charges Hague Misleading Catholics on True Facts of Constitution Revision,” Bergen Evening Record 26 October, 1944; "Revision Attack Sabotage - Edge: Not Harmful to Catholic Interests, He Says," Hudson Dispatch 26 October 1944; "Hague Using New Lie Each Day about Charter, Edge Claims," Plainfield Courier News 26 October,I944; "Edison 'Sorry' Hague Became Charter Issue," Plainfield Courier News 26 October, 1944.

34. Letter from Frank Hague to "Fellow Citizens" (of Jersey City), ca. October 1944:1, Glover Papers; letters from James Kearney, Jr. to Ralph Glover, ca. October I944:I, 
Glover Papers.

35. "Catholic Group Endorses New Constitution," Plainfield Courier News 27 October, 1944; "Catholics Back Charter; Score Bigotry Attack," The Elizabeth Daily Journal 27 October, 1944; "Catholic Committee for New State Constitution," Bergen Evening Record 26 October, 1944; Connors, op. cit.:I06.

36. "Van Riper Lashes Church Tax Rumor as 'Treacherous Lie'," Plainfield Courier News 27 October, 1944; “Easy Divorce Seen Constitutional Peril: An Editorial,” The Jersey Journal 27 October, I944; "Sewell Says Churches Stay Untaxed; Judge Backs Edge in Claim Constitution Preserves Exemption," The Jersey Journal 28 October, I944; "Lawyer Denies Revision Harmful to Catholicy," Hudson Dispatch 28 October, I944; "Pearse Fears Charter Would Mean Tax on Charitable Groups," Hudson Dispatch 28 October 1944.

37. "Constitution Drive Engrosses; Opposition to Revision is Hit Hard in its Attempt to Split Many Groups; Catholics Give Backing; Legion Heads Favor Change and Farm Leaders Join Move for November 7 'Yes' Vote," New York Times 29 October, I944; "Edge Proposes Harry Moore as Head of 'Railroad Lobby', Plainfield Courier News 3 I October, I944; "K. of C. Members Rap Revision,” Elizabeth Daily Journal 30 October, 1944; "Churchmen Defend Charter," Elizabeth Daily Journal 30 October, 1944.

38. “Urges Catholics Reject Revision: Bergen Priest Hits 'Hitler'Tactics on Framers," Hudson Dispatch 3 November, 1944.

39. Letter from Ralph Glover to parish priests, ca. November 1944:I; reprint of The Tablet, ca. October/November I944:I-3; Connors, op. cit:I07.

40. “Edge Hits 'Bigotry': He Declares Religious Issue will be Boomerang,” Newark Evening News 3 November, 1944.

4I. "Edison Deplores Religious Issue: Accuses Hague of Appealing to Bigotry in Attack on New Charter," Newark Evening News 3 November, 1944.

42. Letter T. J. W. (Thomas J. Walsh) to parish priests, ca. November I944, Walsh Files, Seton Hall University Archives, Archdiocese of Newark Collection.

43. "Urge Catholics Oppose Revision: Priests Call on Parishioners to Cast 'No' Votes," Hudson Dispatch 6 November, 1944; "Catholics Get Word on Voting: Father Kelley Urges Rejection of New Constitution,” Newark Sunday Call 5 November, I944; “Catholics Asked at Services to Oppose Revision,” Jersey Observer 6 November, 1944.

44. 'Edge Says Hague 'Dupes' Catholics: Mayor Arouses Unfounded Religious Fears, He Holds," Hudson Dispatch 7 November, 1944.

45. Transcript of the "Address by Governor Edge, 6 November, 1944: Radio Station WOR; Sponsored by the New Jersey Republican State Committee," 6 November, I944:I-4.

46. "The Drumbeat of Politics," The Oranges and Maplewood May 1947. It is interesting to note that Kelley was regarded as a personal enemy of Attorney General Walter Van Riper as the latter was allegedly responsible for bottling the Bus Bill in the New Jersey assembly for years. Van Riper was also an enemy of Hague having attacked the mayor's "Horse Bourse" gambling racket, after which the Jersey City Boss politically ruined Van Riper, who had been considered to be a lock as a future New Jersey governor.

47. Letter from A. F. Heck to Thomas J. Walsh, I3 September, I937; memo of Monsignor 
McClary to Thomas J. Walsh to A. F. Heck, 5 October, 1937; Dayton D. McKean, The Boss: The Hague Machine in Action (Boston, 1960) referenced in Richard J. Connors, A Cycle of Power: The Career of Jersey City Mayor Frank Hague (Metuchen, NJ, I97I).

48. Connors, A Cycle of Power.

49. "Mayor Hague's Long Shadow," New Republic(95) I5 June, I938:I43; Willard Weiner, "Hague is the Law," New Republic (II0) 3I January, I944:I45-I46; "Monsignor Glover Gets National Catholic Charities Post," Hudson Dispatch 23 November, I944; Frank Hague letter to Bishop John J. O'Connor of the Diocese Newark, 3 December, 1925, Glover Files.

50. Connors, A Cycle of Power, 89-92; Joseph H. Brady, The Most Reverend Thomas Joseph Walks S.T.D.J.C.D. Priest of the Catholic Church; I900-, Chancellor of the Diocese of Buffalo; 1900-I018, Third Bishop of the Diocese of Trenton; 1918-1937, Assistant to the Pontifical Throne; 1922-, Fifth Bishop of the Diocese of Newark; 1928-1937, First Archbishop of the Archdiocese of Newark; I938-(South Orange, NJ: Seton Hall College, I950):I-4; Thomas J. Walsh, letter to Frank Hague, 2 June, 1930, Walsh Files, Seton Hall University Archives, Archdiocese of Newark Collection.

5I. Platt, 276-277.

52. Thomas Fleming, New Jersey: A History (New York, I984 [1977]):189. 